\title{
Impact of woody encroachment on soil organic carbon and nitrogen in abandoned agricultural lands along a rainfall gradient in Italy
}

\author{
G. Alberti - V. Leronni - M. Piazzi $\cdot$ F. Petrella $\cdot$ P. Mairota $\cdot$ \\ A. Peressotti $\cdot$ P. Piussi $\cdot$ R. Valentini $\cdot$ L. Gristina $\cdot$ \\ T. La Mantia $\cdot$ A. Novara $\cdot$ J. Rühl
}

Received: 10 January 2011/Accepted: 29 April 2011/Published online: 15 May 2011

(C) Springer-Verlag 2011

\begin{abstract}
Land use changes represent one of the most important components of global environmental change and have a strong influence on carbon cycling. As a consequence of changes in economy during the last century, areas of marginal agriculture have been abandoned leading to secondary successions. The encroachment of woody plants into grasslands, pastures and croplands is generally thought to increase the carbon stored in these ecosystems even though there are evidences for a decrease in soil carbon stocks after land use change. In this paper, we investigate the effects of
\end{abstract}

\author{
G. Alberti $(\bowtie) \cdot$ A. Peressotti \\ Department of Agricultural and Environmental Sciences, \\ University of Udine, Via Delle Scienze 208, \\ 33100 Udine, Italy \\ e-mail: alberti@uniud.it \\ V. Leronni · P. Mairota \\ Dipartimento di Scienze Agro-Ambientali e Territoriali, \\ University of Bari, Bari, Italy \\ M. Piazzi · F. Petrella \\ Istituto per le Piante da Legno e l'Ambiente (IPLA), Turin, Italy \\ P. Piussi \\ Department of Forest Science and Resources, \\ University of Tuscia, Viterbo, Italy \\ R. Valentini \\ Department of Agriculture and Forest Sciences \\ and Technologies, University of Florence, Florence, Italy \\ L. Gristina · A. Novara \\ Dipartimento Saga, University of Palermo, Palermo, Italy \\ T. La Mantia \\ Dipartimento Demetra, University of Palermo, Palermo, Italy \\ J. Rühl \\ EnBioTech s.r.1., Palermo, Italy
}

woody plant invasion on soil carbon and nitrogen stocks along a precipitation gradient $(200-2,500 \mathrm{~mm})$ using original data from paired experiment in Italian Alps and Sicily and data from literature (Guo and Gifford Glob Change Biol 8(4):345-360, 2002). We found a clear negative relationship $\left(-0.05 \% \mathrm{C} \mathrm{mm}^{-1}\right)$ between changes in soil organic carbon and precipitation explaining $70 \%$ of the variation in soil C stocks after recolonization: dry sites gain carbon (up to $+67 \%$ ) while wet sites lose carbon (up to $-45 \%$ ). In our data set, there seem to be two threshold values for soil carbon accumulation: the first one is $900 \mathrm{~mm}$ of mean annual rainfall, which separates the negative from the positive ratio values; the second one is $750 \mathrm{~mm}$, which divides the positive values in two groups of sites. Most interestingly, this threshold of $750 \mathrm{~mm}$ corresponds exactly to a bioclimatic threshold: sites with $<750 \mathrm{~mm}$ mean annual rainfall is classified as thermo-mediterranean sites, while the ones $>750 \mathrm{~mm}$ are classified as mesomediterranean sites. This suggests that apart from rainfall also temperature values have an important influence on soil carbon accumulation after abandonment. Moreover, our results confirmed that the correlation between rainfall and trend in soil organic carbon may be related to nitrogen dynamics: carbon losses may occur only if there is a substantial decrease in soil nitrogen stock which occurs in wetter sites probably because of the higher leaching.

Keywords Land use change - Soil carbon . Precipitation gradient $\cdot$ Secondary succession

\section{Introduction}

In recent decades, knowledge of the role of soils as source or sink for carbon (C) on a global scale has become vital 
for assessing changes in $\mathrm{CO}_{2}$ atmospheric concentrations. Among the organic $\mathrm{C}$ reservoirs in terrestrial ecosystems, soil organic $\mathrm{C}$ has potential to sequester the largest amount of $\mathrm{C}$ for the longest time period. Some authors estimated that soils contain approximately twice as much $\mathrm{C}$ as the atmosphere or terrestrial vegetation. Schimel (1995), Watson et al. (2000) and Dixon et al. (1994) estimated that forest ecosystems contain approximately half of the total terrestrial $\mathrm{C}$ pool, with two-thirds of this stock residing in forest soils. Organic carbon (OC) accumulation in soils reflects the balance of $\mathrm{C}$ inputs as organic matter (returns of plant/root residues) and $\mathrm{C}$ losses from the soil (as carbon dioxide, dissolved $\mathrm{OC}$ and loss through erosion) (Lal 2004). At steady state, each soil has a theoretical equilibrium $\mathrm{C}$ content depending on the nature of vegetation, precipitation and temperature (Paul et al. 2002; Guo and Gifford 2002, Dawson and Smith 2007). This equilibrium between inflows and outflows can be disturbed by land use change until a new equilibrium is reached in the new ecosystem. Thus, after the land use change, soil can act as a source or a sink of $\mathrm{C}$ according to the ratio between inflows and outflows.

In the Northern midlatitudes, one of the most important land use change of the last century has been the abandonment of agricultural areas, such as meadows, pastures and croplands. In Europe, $12.9 \%$ of the 'Arable Land and Permanent Crops' have been abandoned between 1961 and 2001, corresponding to ca. $195,000 \mathrm{~km}^{2}$ (FAO Database 2001). Within such areas, secondary succession dynamics may cause within few decades a complete change in vegetation composition and structure (Ellenberg 1982; Debussche et al. 1996; Mather 1992; Piussi 2000; Knops and Tilman 2000; La Mantia et al. 2008; Rühl and Pasta 2008; Rühl et al. 2006; Kuemmerle et al. 2009). One general trend of these succession dynamics is a gradual change from herbaceous to woody plant communities, but there is no overall rule for the direction and pace of these changes because there are many factors which influence the course of succession (meso and microclimatic conditions, distance of dispersal centres and the presence of dispersal vectors, active and passive facilitation mechanisms, the intensity and frequency of disturbances such as wildfires and herbivory, intra and infraspecific competition mechanisms, soil characteristics, etc.). Concerning the C-cycle, the change from herbaceous to woody plant communities goes along with an increase in plant biomass (Gingrich et al. 2007), but, while an increase in C stored in plant biomass is obvious although difficult to quantify, there is considerable uncertainty about the magnitude and even the direction of changes in soil $\mathrm{C}$ stocks after agricultural abandonment. Several studies have reviewed the effect of agricultural abandonment on soil C stocks (Knops and Tilman 2000; Guo and Gifford 2002; Jackson et al. 2002;
Paul et al. 2002; Davis et al. 2003; Alberti et al. 2008), but data are highly variable, with soil $\mathrm{C}$ either increasing or decreasing depending generally on the type of land use change. For example, while an increase in soil $\mathrm{C}$ after shifting from cropland to secondary forest is generally reported, a decrease from pasture to secondary forest or forest plantation is also reported (Paul et al. 2002; Guo and Gifford 2002; Alberti et al. 2008). Intriguingly, Jackson et al. (2002) found a negative relationship between precipitation and changes in soil $\mathrm{C}$ content when cultivated grasslands are invaded by woody vegetation with drier sites gaining and wetter sites losing soil organic $\mathrm{C}$. They also estimated that in some high-rainfall sites the losses of $\mathrm{C}$ could even outweigh the gains in plant carbon. According to some modelling works (Halliday et al. 2003; Kirschbaum et al. 2008), C losses are likely to occur when there is also a decrease in nitrogen $(\mathrm{N})$ stock. Thus, the correlation between rainfall and trend in soil organic $\mathrm{C}$ may be related to $\mathrm{N}$ dynamics.

In Italy, agricultural land abandonment rates are higher than the European percentage value: between 1961 and 2001, 29.7\% of the "Arable Land and Permanent Crops" have been abandoned, corresponding to $46,320 \mathrm{~km}^{2}$ (FAO database). A part of these areas has undergone colonization by woody species: in fact, according to the Italian National Statistical Bureau (ISTAT), during the period 1950-1990, total forest area has increased by $17.5 \%$. Forest recovery characterizes both the Alps and the Appenines (Piussi 2002; Corona et al. 2005) and this woody encroachment into abandoned croplands, meadows and grasslands is generally thought to lead to an increase in the $\mathrm{C}$ stored in the whole ecosystem (Guo and Gifford 2002). Also in the Southern Mediterranean part of Italy, where forest recovery after abandonment needs longer time periods and is often inhibited by disturbances such as wildfires and pasture, a significant increase in total soil $\mathrm{C}$ was measured after crop abandonment (La Mantia et al. 2007; Costa G e La Mantia 2005). However, even if agricultural land abandonment is a widespread phenomenon in Italy, detailed studies on $\mathrm{C}$ sequestration in soils after abandonment are lacking and few data are available to confirm or to reject the previously mentioned dynamics. These shortcomings may now be overcome since from 2008 to 2010 data on $\mathrm{C}$ sequestration in soils after land abandonment have been collected by the project CarboItaly, funded by Italian Ministry of Environment. In the present manuscript, we present some of the results of the project, analysing data from two of the national study sites [(1) the Pre-Alps in Northern Italy, and (2) Sicily in Southern Italy] with the aim to improve the national carbon accounting.

In the present paper, we address the following questions: does agricultural land abandonment lead to a reduction or an increase in organic carbon in soil in the two studied 
Italian sites? What environmental factors determine such changes? Does the amount of rainfall play a role as it has been suggested by some previous studies?

\section{Materials and methods}

\section{Site description}

Five study areas in the Pre-Alps and seven study areas in Sicily were chosen. The main environmental characteristics of each site are listed in Table 1.

Obviously, due to the differences in environmental factors such as mean annual rainfall, geological substrate and bioclimate, secondary succession dynamics of vegetation communities were not homogeneous for all the sites. Apart from this 'macro'-heterogeneity due to zonal environmental factors, succession dynamics between the sites differ also due to local factors, such as the distance of dispersal sources, the presence of dispersal vectors and disturbance factors. There was, however, one homogeneous factor within the study areas: in the Alps, preabandonment plots were always managed meadows and post-abandonment plots were always secondary forests, while in Sicily pre-abandonment plots were always croplands, and post-abandonment plots were always secondary shrublands. This choice was necessary because in the Alps meadow abandonment is the most common abandonment type, while in Sicily, this type is almost absent, as almost all agricultural abandonment occurs on croplands.

For each paired site, two $530 \mathrm{~m}^{2}$ plots were selected according to the criteria reported by Conteh (1999) and Davis et al. (2004). For the selection, paired plots were required to have similar soils, slope, aspect and elevation, but contrasting land use. In the Pre-Alps, paired plots were (1) a managed meadow characterized by perennial grasses and (2) a secondary forest, represented by meadows abandoned 10-75 years ago. As said previously, all secondary forests considered in the present study have the same species composition and can be classified as ash and maple mixed stands. Stand age was estimated according to the methodology proposed by Alberti et al. (2009) based on historical maps, aerial photographs, site visits and wood cores. All Pre-Alps sites were characterized by an oro- or supra-mediterranean bioclimatic thermotype (sensu RivasMartínez 2008).

In Sicily, paired plots were (1) a cultivated cropland characterized by annual vegetation and (2) shrubland or open maquis, represented by old fields abandoned 10-40 years ago. In shrublands, the most common species were Spartium junceum L. and Pyrus pyraster (L.) Du Roi, while most common species in open maquis were Pistacia lentiscus L., Quercus pubescens Will. and Quercus ilex L. Abandonment age was estimated by analysing historical aerial photographs. All Sicily sites were characterized by a thermo- or mesomediterranean bioclimatic thermotype. For both Pre-Alps (Alberti et al. 2008) and Sicily (Drago et al. 2002), mean annual rainfall and temperature values were acquired from Regional GIS Maps or directly from close by weather stations where present.

\section{Soil sampling}

Soil sampling was conducted in 2008 in the Pre-Alps and in 2010 in Sicily. Sampling area within each land use was chosen very carefully to minimize the effects of spatial

Table 1 Main environmental characteristics of study areas

\begin{tabular}{|c|c|c|c|c|c|c|c|c|}
\hline $\mathrm{L}$ & Site & $\begin{array}{l}\text { Altitude } \\
\text { [m a.s.1.] }\end{array}$ & $\begin{array}{l}\text { Rain } \\
{[\mathrm{mm}]}\end{array}$ & $\begin{array}{l}\mathrm{T} \\
\left({ }^{\circ} \mathrm{C}\right)\end{array}$ & $\begin{array}{l}\text { Bioclimatic } \\
\text { thermotype }\end{array}$ & Geological substrate & Land use pre/post & $\begin{array}{l}\text { Age of abandonment } \\
\text { (years) }\end{array}$ \\
\hline A & Chiusa Pesio & 900 & 1,430 & 12 & n.a. & Sandstone/limestone & Meadow/forest & 23 \\
\hline A & Forgaria del Friuli & 800 & 2,055 & 13 & Supra & Sandstone/limestone & Meadow/forest & 28 \\
\hline A & Trasaghis & 1,000 & 2,130 & 13 & Supra & Sandstone/limestone & Meadow/forest & 48 \\
\hline A & Faedis & 800 & 2,265 & 13 & Supra & Sandstone/limestone & Meadow/forest & 47 \\
\hline A & Taipana & 600 & 2,415 & 8 & Oro & Sandstone/limestone & Meadow/forest & 67 \\
\hline S & Trappeto & 150 & 650 & 17.5 & Thermo & Sand/limestone & Cropland/maquis & 15 \\
\hline S & Santa Ninfa & 450 & 654 & 17 & Thermo & Clay & Cropland/shrubland & 25 \\
\hline S & Misilmeri & 250 & 700 & 18 & Thermo & Clay & Cropland/shrubland & 35 \\
\hline S & San Martino & 750 & 750 & 14.5 & Meso & Limestone & Cropland/shrubland & 11 \\
\hline S & Giacalone & 750 & 750 & 14.5 & Meso & Limestone & Cropland/shrubland & 30 \\
\hline S & Maletto & 1,000 & 900 & 12.5 & Meso & Volcanic & Cropland/shrubland & 15 \\
\hline S & Zafferana Etnea & 750 & 1,100 & 14 & Meso & Volcanic & Cropland/shrubland & 15 \\
\hline
\end{tabular}

$L$ study area with $A$ Alps and $S$ Sicily, $T$ mean annual temperature, Bioclimate thermotype of bioclimate sensu Rivas-Martinez; Land use before abandonment (pre) and after abandonment (post). n.a. not available 
variability and to represent the land use investigated. After removing the litter, mineral soil samples were collected at depths of $0-10 \mathrm{~cm}$, and $10-30 \mathrm{~cm}$, using a 340 and a $680 \mathrm{~cm}^{3}$ cylinder, respectively. At each site, three soil samples were collected along a transect at approximately $10 \mathrm{~m}$ intervals. The samples were gently broken to pass a 2-mm sieve and air dried, ground to a fine powder, treated with $\mathrm{HCl} 2: 1$ to remove carbonates and then analysed for organic $\mathrm{C}$ and $\mathrm{N}$ using a CHN-Elemental Analyser.

The soil organic $\mathrm{C}$ content was estimated in percentage terms and converted to tons per hectare using bulk density and soil depth. Bulk density of fine $(<2 \mathrm{~mm})$ fraction of mineral soil was measured using the volume of the collected sample and the weight of sieved dry soil in the sample (Blake and Hartge 1986).

\section{Statistical analysis}

The scope of the paired experiment design was to compare effects of meadow/cropland to woody community transformation without initial differences in soil properties. For every paired site, we computed the soil organic $\mathrm{C}$ and $\mathrm{N}$ content change from pre- to post-abandonment as:

$\Delta \mathrm{C} \%=\left(\mathrm{C}_{\text {post }}-\mathrm{C}_{\text {pre }}\right) / \mathrm{C}_{\text {pre }}$

$\Delta \mathrm{N} \%=\left(\mathrm{N}_{\text {post }}-\mathrm{N}_{\text {pre }}\right) / \mathrm{N}_{\text {pre }}$

where $\mathrm{C}_{\text {post }}=$ soil organic $\mathrm{C}$ content in the post-abandonment plots and $\mathrm{C}_{\text {pre }}=$ soil organic $\mathrm{C}$ content in the preabandonment plots; $\mathrm{N}_{\text {post }}=$ soil organic $\mathrm{N}$ content in the post-abandonment plots and $\mathrm{N}_{\text {pre }}=$ soil organic $\mathrm{N}$ content in the pre-abandonment plots.

Table 2 Soil organic carbon contents, soil carbon and nitrogen changes ( $\Delta \mathrm{C} \%$ and $\Delta \mathrm{N} \%$, respectively) for each study site and mean values for three rainfall groups (in brackets standard deviation) ( $C$ pre
Proportional changes in soil organic $\mathrm{C}$ and $\mathrm{N}$ with woody plant invasion were then analysed on their trends in function of: (1) mean annual rainfall, (2) study area (PreAlps and Sicily). Data on pasture to forest plantation land use from the review of Guo and Gifford (2002) were also considered. In order to analyse if different levels of mean annual rainfall influence soil carbon storage, a one-way ANOVA was used to compare three levels of rainfall ( $<750 \mathrm{~mm}$ vs. $750-900 \mathrm{~mm}$ vs. $>900 \mathrm{~mm}$ ) with respect to the standardized ratio of total soil carbon in abandoned sites : total soil carbon in cultivated sites. One-way ANOVA was computed in combination with Holm-Sidak's method of pairwise multiple comparison (overall level of significance $P<0.05$ ). Statistical tests were computed with Sigma Stat 3.0.

\section{Results}

Soil carbon contents and $\Delta \mathrm{C} \%$ values are reported in Table 2 and Fig. 1. In the Pre-Alps sites, organic soil C content in cultivated meadows ranges from 80 to $116 \mathrm{t} \mathrm{ha}^{-1}$, while their abandonment leads to a decrease in $\mathrm{C}$ content (post-abandonment sites: 48-104 $\mathrm{t} \mathrm{ha}^{-1}$ ). After abandonment, most sites lost between one-third and one-half of their pre-abandonment $\mathrm{C}$ content. On the contrary, abandonment of cropland in the Sicilian sites leads to an increase in $\mathrm{C}$ content (pre-abandonment sites range from 31 to $98 \mathrm{t} \mathrm{ha}^{-1}$, post-abandonment sites range from 30 to $102 \mathrm{t} \mathrm{ha}^{-1}$ ). After abandonment, most sites gained $20-40 \%$ of their pre-abandonment C content.

mean organic carbon content in soil in the pre-abandonment site; $\mathrm{C}$ post means idem in the post-abandonment site)

\begin{tabular}{|c|c|c|c|c|c|}
\hline Site & Precipitation (mm) & $\mathrm{C}$ pre $\left(\mathrm{Mg} \mathrm{C} \mathrm{ha}^{-1}\right)$ & $\mathrm{C}$ post $\left(\mathrm{M} \mathrm{ha}^{-1}\right)$ & $\Delta \mathrm{C} \%$ & $\Delta \mathrm{N}(\%)$ \\
\hline Taipana & 2,415 & $106.7(16.0)$ & $72.6(14.5)$ & -45 & -35 \\
\hline Faedis & 2,265 & $84.5(10.0)$ & $48.0(4.1)$ & -43 & -47 \\
\hline Trasaghis & 2,130 & $80.8(7.1)$ & $52.9(3.0)$ & -34 & -41 \\
\hline Forgaria del Friuli & 2,055 & $99.4(19.3)$ & $67.5(2.8)$ & -32 & -38 \\
\hline Chiusa Pesio & 1,430 & $115.7(0.0)$ & $103.6(4.9)$ & -10 & -3 \\
\hline Zafferana Etnea & 1,100 & $41.1(6.9)$ & $29.5(15.0)$ & -31 & -7 \\
\hline Mean $(>900 \mathrm{~mm})$ & & 88.0 & 62.3 & -30 & -29 \\
\hline Maletto & 900 & $57.7(9.9)$ & $74.7(6.7)$ & 29 & -3 \\
\hline San Martino & 750 & $98.3(6.8)$ & $102.0(20.3)$ & 4 & -8 \\
\hline Giacalone & 750 & $76.6(18.7)$ & $92.7(20.1)$ & 21 & -9 \\
\hline Mean $(750-900 \mathrm{~mm})$ & & 77.5 & 89.8 & 18 & 7 \\
\hline Misilmeri & 700 & $59.8(0.0)$ & $97.7(0.0)$ & 63 & 44 \\
\hline Santa Ninfa & 654 & $53.3(2.3)$ & $89.0(5.1)$ & 67 & 50 \\
\hline Trappeto & 650 & $31.1(2.4)$ & $47.6(2.8)$ & 53 & 8 \\
\hline Mean $(<750 \mathrm{~mm})$ & & 48.1 & 78.1 & 61 & 34 \\
\hline
\end{tabular}



standard deviation of $\Delta \mathrm{C} \%$ for types of secondary succession (above) and rainfall ranges $(<750 \mathrm{~mm}$ vs. $750-900 \mathrm{~mm}$ vs. $>900 \mathrm{~mm})$ (below)
Fig. 1 Medium value and

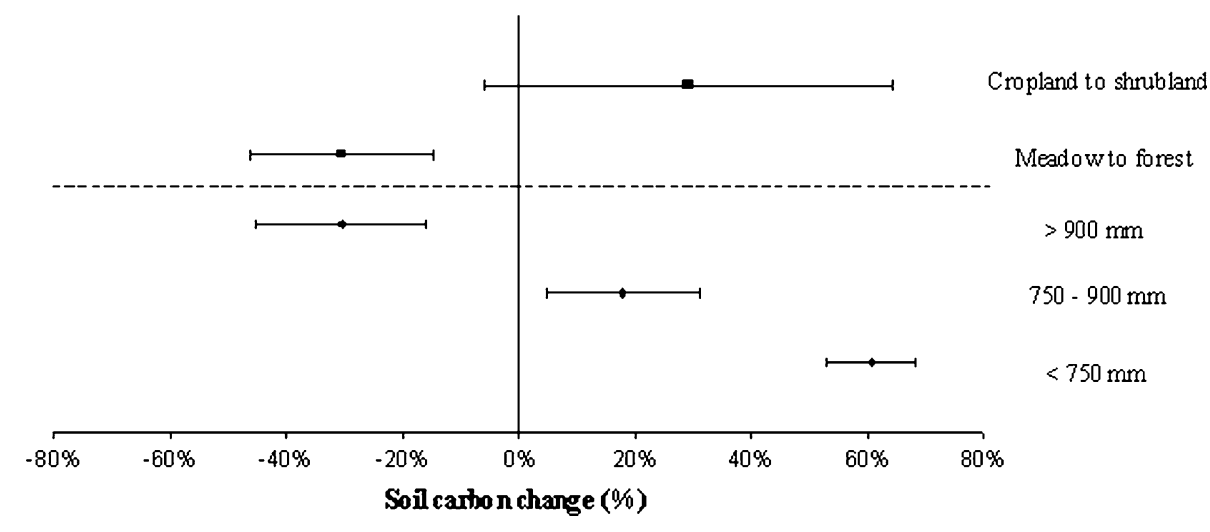

In the site of Zafferana Etnea, we recorded a decrease in $\mathrm{C}$ content from pre- to post-abandonment. This site is the one with the highest rainfall value recorded in Sicily $(1,100 \mathrm{~mm})$.

Independently of the previous land use, $\Delta \mathrm{C} \%$ is negative for all sites with mean annual rainfall above $900 \mathrm{~mm}$, while it is positive for all sites with mean annual rainfall below $900 \mathrm{~mm}$ (see also Fig. 1). In addition, there is a noteworthy difference between $\Delta \mathrm{C} \%$ values of the sites with rainfall ranges from 750 to $900 \mathrm{~mm}$ and the sites with rainfall ranges below $750 \mathrm{~mm}$. One-way ANOVA showed that there are significant differences $(P<0.001)$ between the three treatment groups. Pairwise comparison showed significant differences $(P<0.001)$ for all pairwise comparisons. Thus, we can affirm that the $\Delta \mathrm{C} \%$ varies along a rainfall gradient. Also, linear regression analyses showed that there is a correlation between mean annual rainfall and $\Delta \mathrm{C} \%$ (linear regression computed on all sites and Guo and Gifford data: $r^{2}=0.70 ; P<0.001 ; n=17$ ) (Fig. 2a). Particularly, the lowest values of $\Delta \mathrm{C} \%$ depend on highest rainfall values (linear regression computed on Pre-Alps and Guo and Gifford sites: $\left.r^{2}=0.96 ; P<0.001 ; n=10\right)$. On the contrary, high $\Delta \mathrm{C} \%$ were determined by low rainfall values (linear regression computed on Sicilian sites: $\left.r^{2}=0.70 ; P<0.05 ; n=7\right)$. A similar trend in $\Delta \mathrm{N} \%$ was also detected for soil organic $\mathrm{N}$ (linear regression computed on all sites considered in the present study: $r^{2}=0.67 ; P<0.001 ; n=13$; Fig. $\left.2 b\right)$, with increasing rainfall, higher amounts of $\mathrm{N}$ were lost. These changes in $\mathrm{N}$ seems to drive changes in soil organic $\mathrm{C}\left(r^{2}=0.81\right.$; $P<0.001 ; n=13$; Fig. 3): under low rainfall, system retained $\mathrm{C}$ because losses of $\mathrm{N}$ were compensated by a slight increase in soil $\mathrm{C} / \mathrm{N}$ ratio, but with increasing rainfall, soil $\mathrm{C}$ was lost due to a loss of system nitrogen stocks which were not sufficiently compensated by an increase in $\mathrm{C} / \mathrm{N}$ ratio (data not shown). Hence, the rainfall-driven effect on $\mathrm{N}$ dynamics determined changes in soil $\mathrm{C}$ across the rainfall gradient that mirrored the pattern shown in Fig. 2a.
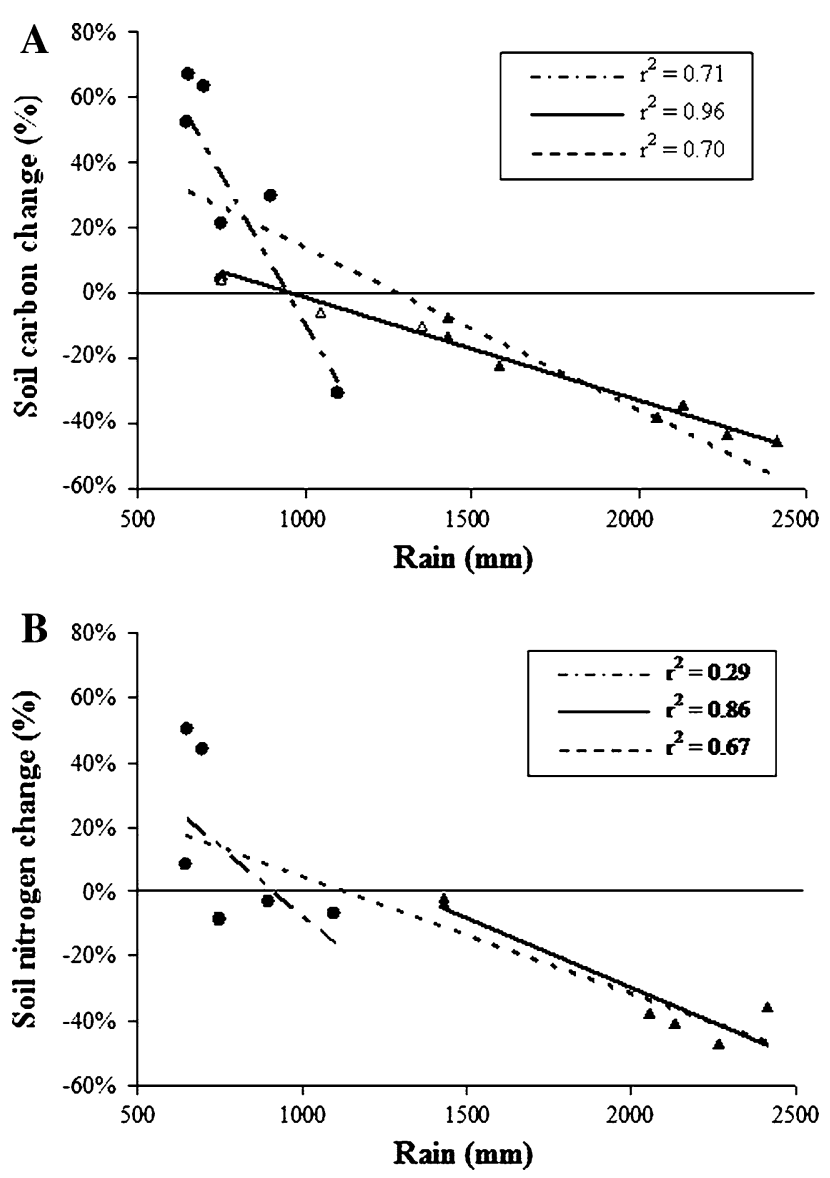

Fig. 2 Soil carbon change (panel A) and soil nitrogen change (panel $B)$ versus annual rainfall gradient with linear regressions. Circles (dash-dotted line) from cropland to shrubland/maquis sites (Sicilian study sites), Full triangles (solid line) from meadows to forest sites (Pre-Alps study sites), Empty triangles data from Guo and Gifford 2002 and all sites (dashed line)

\section{Discussion}

Regarding the Pre-Alps sites, the average soil C loss in the secondary forests $(-30 \%)$ is in accordance within the range reported by Guo and Gifford (2002) for forest plantations and with other studies (Paul et al. 2002; Davis 


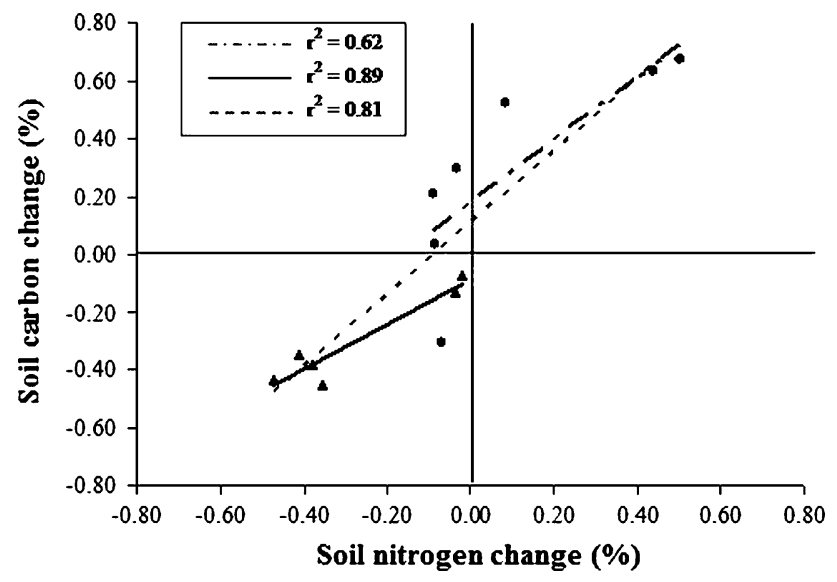

Fig. 3 Soil carbon change versus soil nitrogen change with linear regressions. Circles (dash-dotted line) from cropland to shrubland/ maquis sites (Sicilian study sites); Full triangles (solid line) from meadows to forest sites (Pre-Alps study sites), all sites (dashed line)

and Condron 2002; Alberti et al. 2008). On the contrary, Hooker and Compton (2003) reported an annual increase in soil $\mathrm{C}$ of $0.52 \mathrm{Mg} \mathrm{C} \mathrm{ha}{ }^{-1}$ year $^{-1}$ and also an annual decrease in soil $\mathrm{N}$ of $-12.4 \mathrm{~kg} \mathrm{~N} \mathrm{ha}^{-1}$ year $^{-1}$, in a coniferous secondary succession (Pinus strobus L.), and similar results are reported by Thuille et al. (2000) in a chronosequence of Norway spruce (Picea abies K.) stand regenerating on abandoned meadows in the Southern Alps. These differences can be explained by the high precipitations (Paul et al. 2002; Jackson et al. 2002), the vegetation type (mixed broadleaf forest), the previous land use (Piussi 2000) and the long time lags for changes in litter inputs. Concerning the last point, organic matter in the abandoned grassland continued its decomposition while young trees did not begin to contribute to soil organic $\mathrm{C}$ pools through the production of litter and woody products. For example, Alberti et al. (2008) reported that 75 years may be a too short period to observe an increase in soil $\mathrm{C}$ after colonization even though litter is still accumulating in the 75-year-old stand. Also, Jackson et al. (2002) reported a strong link between soil $\mathrm{C}$ stock change and rainfall: the higher the annual precipitation, the higher the $\mathrm{C}$ loss from soil after conversion. Moreover, regenerating forests produce litter that is more resistant to decomposition compared to the residues produced by previous agricultural crops, and tree roots are less important as a source of organic matter than grass roots because a large fraction of tree roots survive intact for many years. This could also explain the reduction in soil $\mathrm{C}$ content with secondary succession.

In Sicily, we found the highest soil carbon accumulation after abandonment in the driest sites.

It can be speculated that the differences in soil organic carbon dynamics are dominated by the different land use conversions (cropland to forest versus meadow to forest); however, Fig. 2a shows that within the land use conversion type, the relationship with rainfall is rather evident, indicating that it plays a fundamental role in determining gain or losses of carbon.

Furthermore, it is noteworthy that in our data set there seem to be two threshold values for soil carbon accumulation: the first one is $900 \mathrm{~mm}$ of mean annual rainfall, which separates the negative from the positive ratio values; the second one is $750 \mathrm{~mm}$, which divides the positive values in two groups of sites. Most interestingly, this threshold of $750 \mathrm{~mm}$ corresponds exactly to a bioclimatic threshold: our sites with $<750 \mathrm{~mm}$ mean annual rainfall are classified as thermo-mediterranean sites, while the ones $>750 \mathrm{~mm}$ are classified as mesomediterranean sites (Drago et al. 2002). Since bioclimatic thermotype sensu RivasMartínez $(1944,2008)$ is calculated using mean annual temperature, mean of the maximum temperatures of the coldest month and mean of the minimum temperatures of the coldest month, but not rainfall values, apart from rainfall, also temperature could, thus, play a role as an environmental factor influencing soil carbon accumulation after abandonment.

The present study also showed a change in soil $\mathrm{N}$ stock after land use change. It is noteworthy that other studies (e.g. Halliday et al. 2003; Kirschbaum et al. 2008) have reported that changes in soil $\mathrm{C}$ can be understood only considering the $\mathrm{N}$ budget. In fact, according to Rastetter et al. (1992), changes in C storage in N-limited ecosystem are mainly governed by changes in three biogeochemical cycles: (1) changes in total $\mathrm{N}$ stocks, (2) changes in $\mathrm{C} / \mathrm{N}$ ratios in key pools and (3) redistribution of $\mathrm{N}$ among pools with different $\mathrm{C} / \mathrm{N}$ ratio. The strong increase in $\mathrm{N}$ loss rates with increasing rainfall found in the present study could be mainly due to the drainage from the system according to previous studies (Parfitt et al. 1997, 2003; Scott et al. 1999; Randall and Ila 2001). Moreover, some modelling studies (Halliday et al. 2003; Kirschbaum et al. 2008) reported that $\mathrm{C}$ losses may occur only if there is a substantial decrease in soil $\mathrm{N}$ stock and that the rate of change in both $\mathrm{C}$ and $\mathrm{N}$ stocks is related to annual rainfall. The $\mathrm{N}$ stock increase in our Mediterranean sites can be explained by a progressive inhibition of nitrification under semiarid conditions (Carreira et al. 1994) and has been previously reported in literature (Robertson and Vitousek 1981; Bonet 2004).

\section{Conclusions}

The question whether wood encroaching can represent a sink or source of carbon is still an intriguing question that shows multiple facets according to a number of driving factors. Although we are still not able to provide a fully 
detailed analysis of the process, the results presented in this paper highlighted the importance of rainfall regime in determining gain or losses in soil organic carbon.

The results reported in the present work indicate that the changes in soil organic $\mathrm{C}$ during secondary succession in abandoned grasslands or croplands can be explained by differences in rainfall regimes. The present study underlines the fact that reductions in soil $\mathrm{C}$ after woody encroachment are possible in systems characterized by high rain levels where significant $\mathrm{N}$ losses can occur. Thus, losses of $\mathrm{C}$ are generally restricted to environment that receive large amount of rain and are dominated by drainage such as those in Eastern Alps. Further researches are needed to better understand the role of $\mathrm{N}$ in carbon depletion during secondary successions in wet environments, and data are still lacking for central Italy where the succession processes may have been occurred following different patterns (Piussi 2002).

Acknowledgments This work was financially supported by the Italian government through the FIRB project "Carboitaly", the PRIN project "Methodologies for $\mathrm{CO}_{2}$ uptake accounting in agricultural and forest ecosystems" and PRIN project "The impacts of secondary succession processes on carbon storage in soil and biomass and on biodiversity and the role of dispersal centres and vectors for recolonization processes". We would like to thank Diego Chiabà for the help during field campaigns and lab analysis.

\section{References}

Alberti G, Peressotti A, Piussi P, Zerbi G (2008) Forest ecosystem carbon accumulation during a secondary succession on Eastern Prealps (Italy). Forestry 81:1-11

Alberti G, Peressotti A, Piussi P, Zerbi G (2009) Structure and stand development of secondary forests in Eastern Prealps (Italy). Dendrochronologia 27:173-181

Blake GR, Hartge KH (1986) Bulk density. In: Klute A(ed) Methods of soil analysis, Part 1, 2nd Edn. Agronomy Monograph, vol 9. American Society of Agronomy, Madison, WI, pp 363-375

Bonet B (2004) Secondary succession of semi-arid Mediterranean old-fields in south-eastern Spain: insights for conservation and restoration of degraded lands. J Arid Environ 56:213-233

Carreira JA, Niell FX, Lajtha K (1994) Soil nitrogen availability and nitrification in Mediterranean shrublands of varying fire history and successional age. Biogeochemistry 26:189-209

Conteh A (1999) Evaluation of the paired site approach to estimating changes in soil carbon. Discussion paper 3, of Appendix 6 to Technical Report No 2. Australian Greenhouse Office, Camberra

Corona P, Pompei E, Scarascia Mugnozza G (2005) Stima probabilistica del tasso di espansione annua e del valore al 1990 della superficie forestale nella Regione Abruzzo. Forest@ 2(2): 178-184

Costa G e La Mantia T (2005) Il ruolo della macchia mediterranea nello stoccaggio del carbonio atmosferico. Foresta@ 2(4): 378-387. Online: http://www.sisef.it/

FAO Database (2001) http://faostat.fao.org/faostat/collections?subset= agriculture. Last accessed Nov2010

Davis M, Condron L (2002) Impact of grassland afforestation on soil $\mathrm{C}$ in New Zealand: a review of paired site studies. Aust J Soil Res 40:675-690
Davis MR, Allen RB, Clinton PW (2003) Carbon storage along a stand development sequence in a New Zealand Nothofagus forest. Fort Ecol Manag 177:313-321

Davis M, Wilde H, Tate K (2004) Using paired plots to verify soil carbon change associated with land-use change as predicted from historical soil inventory. SuperSoil 2004: 3rd Australian New Zealand soils conference, University of Sydney, Australia, 5-9 Dec 2004. Published on CDROM. Website: http://www. regional.org.au/au/asssi/

Dawson JJC, Smith P (2007) Carbon losses from soil and its consequences for land management. Sci Total Environ. doi: 10.1016/j.scitotenv.2007.03.023

Debussche M, Escarré J, Lepart J, Houssard C, Lavorel S (1996) Changes in Mediterranean plant succession: old-fields revisited. J Veg Sci 7:519-526

Dixon RK, Brown S, Houghton RA, Solomon AM, Trexler MC, Wisniewski J (1994) Carbon pools and flux of global forest ecosystems. Science 263:185-190

Drago A, Lo Bianco B, Monterosso I (2002) Atlante climatologico della Sicilia. Assessorato agricoltura e foreste. Servizio informativo agrometereologico siciliano. Regione siciliana

Ellenberg H (1982) Vegetation Mitteleuropas mit den Alpen. Ulmer Verlag, Stuttgart

Gingrich A, Karl-Heinz Erb KH, Krausmann F, Gaube V, Haberl H (2007) Long-term dynamics of terrestrial carbon stocks in Austria: a comprehensive assessment of the time period from 1830 to 2000. Reg Environ Change 7:37-47

Guo LB, Gifford RM (2002) Soil carbon stocks and land use change: a meta analysis. Glob Change Biol 8(4):345-360

Halliday JC, Tate KR, McMurtrie RE, Scott NA (2003) Mechanisms for changes in soil carbon storage with pasture to Pinus radiata land-use change. Glob Change Biol 9:1294-1308

Hooker TD, Compton JE (2003) Forest ecosystem carbon and nitrogen accumulation during the first century after agricultural abandonment. Ecol Appl 13(2):299-313

Jackson RB, Banner JL, Jobbagy EG, Pockman WT, Wall DH (2002) Ecosystem carbon loss with woody plant invasion of grasslands. Nature 418:623-626

Kirschbaum MUF, Guo LB, Gifford RM (2008) Why does rainfall affect the trend in soil carbon after converting pastures to forests? Possible explanation based on nitrogen dynamics. For Ecol Manag 255:2990-3000

Knops JMH, Tilman D (2000) Dynamics of soil nitrogen and carbon accumulation for 61 years after agricultural abandonment. Ecology 81(1):88-98

Kuemmerle T, Muller D, Griffiths P, Rusu M (2009) Land use change in Southern Romania after collapse of socialism. Reg Environ Change 9:1-12

La Mantia T, Oddo G, Rühl J, Furnari G, Scalenghe R (2007) Variazione degli stock di carbonio in seguito ai processi di abbandono dei coltivi: il caso studio dell'isola di Pantelleria (Tp). In: a cura di E. Lingua, R. Marzano, G. Minotta, R. Motta, A. Nosenzo, G. Bovio (eds) Atti $V^{\circ}$ Congresso SISEF: Foreste e Società-Cambiamenti, Conflitti, Sinergie Grugliasco(TO), 27-20 Settembre2005. Foresta@ vol 4. no. 1 (Mar 2007), 102-109

La Mantia T, Rühl J, Pasta S, Campisi D, Terrazzino G (2008) Structural analysis of woody species in Mediterranean old fields. Plant Biosyst 142(3):462-471

Lal R (2004) Soil carbon sequestration impacts on global climate change and food security. Science 304:1623-1627

Mather AS (1992) The forest transition. Area 24(4):367-379

Parfitt RL, Percival HJ, Dahlgren RA, Hill LF (1997) Soil and solution chemistry under pasture and radiata pine in New Zealand. Plant Soil 91:279-290

Parfitt RL, Scott NA, Ross DJ, Salt GJ, Tate KR (2003) Land-use change effects on soil $\mathrm{C}$ and $\mathrm{N}$ transformations in soils of high $\mathrm{N}$ 
status: comparisons under indigenous forest, pasture and pine plantation. Biogeochemistry 66:203-221

Paul KI, Polglase PJ, Nyakuengama JG, Khanna PK (2002) Change in soil carbon following afforestation. For Ecol Manag 168:241-257

Piussi P (2000) Expansion of European mountain forests. In: M Price, $\mathrm{N}$ Butt (eds) Forests in sustainable mountain development: a state of knowledge report 2000, CABI Publishing, Wallingford, pp 19-25

Piussi P (2002) Rimboschimenti spontanei ed evoluzioni post coltura. Monti e boschi 3:31-37

Randall GW, Ila DJM (2001) Nitrate nitrogen in surface water as influenced by climatic conditions and agricultural practices. J Environ Qual 30:337-344

Rastetter EB, McKane RB, Shaver GR, Melillo JM (1992) Changes in $\mathrm{C}$ storage by terrestrial ecosystems: how $\mathrm{C}: \mathrm{N}$ interactions restrict responses to $\mathrm{CO}_{2}$ and temperature. Water Air Soil Pollut 64:327-344

Rivas-Martínez S (1994) Bases para una nueva clasificación bioclimática de la Tierra. Folia Botanica Matritensia 10:1-23

Rivas-Martínez (2008) Global bioclimatics (Clasificación biclimática de la Tierra) (versión 01-12-2008). http://www.globalbioclimatics.org
Robertson GP, Vitousek PM (1981) Nitrification potentials in primary and secondary succession. Ecology 62:376-386

Rühl J, Pasta S (2008) Plant succession on Sicilian terraces. Annali di Botanica (Roma) 7:111-126

Rühl J, Pasta S, Schnittler M (2006) A chronosequence study of vegetation dynamics on vine and caper terraces of Pantelleria Island (Sicily). Arch f Natursch Landschaftsforsch Greifswald 45(1): 71-90

Schimel DS (1995) Terrestrial ecosystems and the carbon cycle. Glob Biol Change 1:77-91

Scott NA, Tate KR, Ford-Robertson J, Giltrap DJ, Smith CT (1999) Soil carbon storage in plantation forests and pastures: land-use change implications. Tellus 51B:326-335

Thuille A, Buchmann N, Schulze ED (2000) Carbon stocks and soil respiration rates during deforestation, grassland use and subsequent Norway spruce afforestation in the Southern Alps, Italy. Tree Physiol 20(13):849-857

Watson RT, Noble IR, Bolin B, Ravindranath NH, Verardo DJ, Dokken DJ (2000) Land use, land-use change and forestry: a special report of the Intergovernmental Panel on Climate Change. Cambridge University Press, Cambridge, 388 p 